\title{
About historic stonework in Kraków
}

\author{
Anna Kulig \\ Politechnika Krakowska
}

\begin{abstract}
Massive fragments of portals, mouldings, and columns which are stored in stone collections and museum storage rooms are today of no particular interest. They spur the visitors' imagination only slightly; there, just a piece of stone, carved, yet incomplete, broken. Can this legacy, difficult in perception, be shown in a different way and made memorable? Can it be made close to the audience?

The concepts of the pioneers of conservation of historical objects are worth referencing. Realized concepts testify for an attitude of respect towards the legacy and traditions. Gothic architectural details that were abandoned during demolitions of historical structures in the $19^{\text {th }}$ century, have survived elsewhere, "incrusted" in other structures. It happened in the walls of Collegium Maius, The Bishop Erazm Ciołek Palace, Pusłowscy Palace, Lubomirscy Palace, Tadeusz Stryjeński Palace. They were often treated as native relics. Saved from destruction and from being forgotten they adorn facades, interiors and gardens. Perhaps the idea and the examples of stone collections will spur a reflection and inspiration in designers today.
\end{abstract}

\section{About museum stonework collections}

Several hundred exhibits of architectural stonework accumulated since the $19^{\text {th }}$ century inside storage rooms of the National Museum have been displayed to the public, as part of several outdoor stonework exhibitions, in the gardens and inside museum rooms and study storages over the recent years. The collections include damaged stone works made of dimension stones, parts of e.g. portals, window frames, cornices, wimpergs, etc. The stone works often include architectural sculpture. Where do these pieces come from?

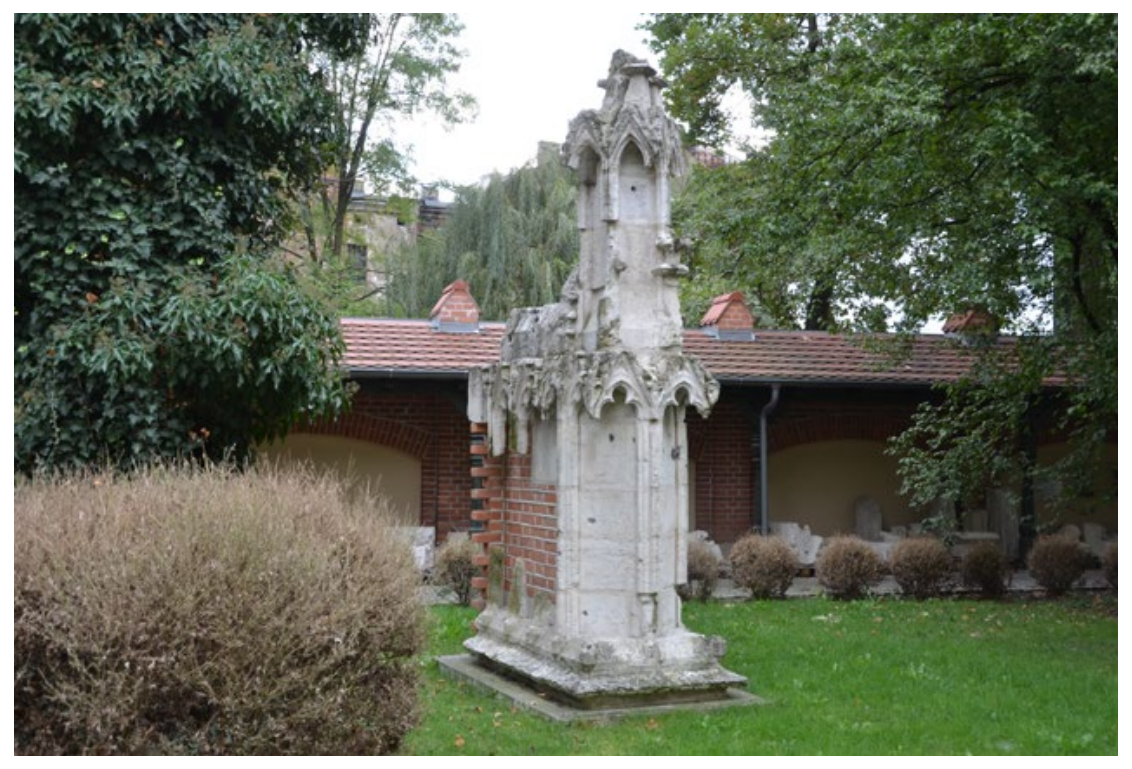

Fig. 1. Kraków, Pałacyk Czapskich, lapidarium w ogrodzie, pinakiel z XIV w.

Stone sculptures and elements of architectural design wore down naturally, mostly due to direct exposure to weather. In the late $19^{\text {th }}$ century multiple restoration and conservation projects were undertaken in Kraków. 
As part of the work, many elements of damaged stonework were replaced and some old details were removed. That is how the museum acquired a large number of pieces representing various architectural styles. Initially they were stored in the Barbican, later on in the garden by the Czapski Palace where the first stonework collection was created. The collections were also exhibited in the Cloth Hall and the Town Hall Tower. In the 1960s the large collection of architectural sculpture and plaster casts was moved to the Szołayski tenement building where it remained unavailable to the public for a long time. In 2010, in the Erazm Ciołek Bishop of Płock Palace, a permanent exhibition opened in the vast basement filled with museum display cases. The original stone works are displayed alongside a collection of architectural sculpture and plaster casts. Their origin and sense is explained by Władysław Łuszczkiewicz, the first Director of the National Museum, "a plaster cast allows for thorough and comprehensive review of sculpture, comparison against other elements in the collection, something that cannot be done with photography or a brief on-site encounter with the original work. In the case of many of the plaster casts, the original works are either inaccessible or non-existent".

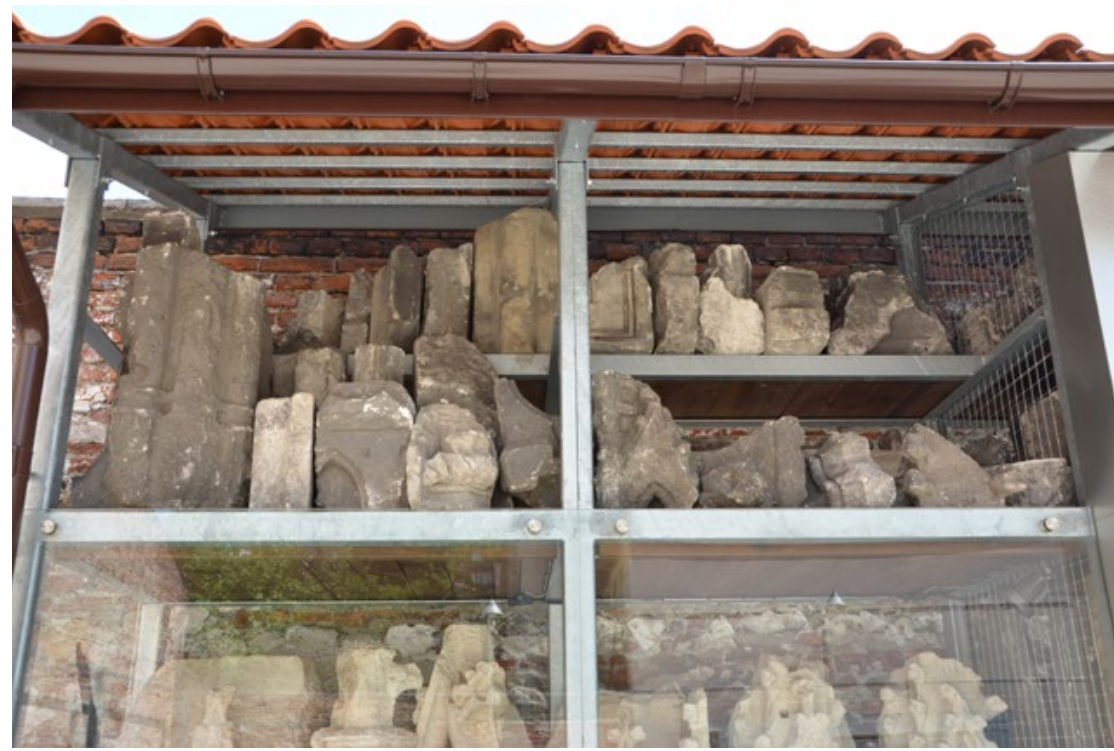

Fig. 2. Kraków, Spichlerz, Plac Sikorskiego 6, lapidarium

The Hutten-Czapski Museum, the oldest branch of the National Museum in Kraków, boasts the most effective stonework collection integrated into the palace garden, with valuable pieces of Krakow's Gothic buildings (Fig. 1). In the garden the exhibits harmonise well with the greenery, with the dominant element being a medieval pinnacle (i.e. an original $14^{\text {th }}$-century pinnacle from Saint Mary's Church). Near the fence there is a collection of diverse details: massive and very small exhibits. The trees and flowers found in the garden provide the perfect background for the collection. Visitors can combine study of the collection with a walk, recreation in the garden or sketching decorative motifs. There are several characteristic exhibits that deserve a mention. Those include pieces of dimension stones made of Jurassic limestone in the late $14^{\text {th }}$ century, e.g.: a) piece of a gable finial with crockets - which are a common element in Gothic architecture - on the edges; b) piece of aedicula that topped the buttress of presbytery in Saint Mary's Church in Kraków. The dimension stone was dressed to serve as the bottom part of a double sloped roof which adheres to the ends of wimpergs; $c$ ) part of aedicula of a buttress of altar wall. It includes a piece of a row of wimpergs. The wimpergs are separated by fleurons. The preserved fragment includes tracery on half of the wimperg and its diamond vault; $d$ ) pieces of pinnacles with parts of decorative wimpergs and crockets on the edges; they formed a part of aedicula of buttresses; e) piece of a portal jamb or window frame of unknown origin, second half of the $14^{\text {th }}$ century; e) corner piece of a straight portal lintel with intertwining muntins and fragments of arches. This is an element of a characteristic, still Gothic, portal from the early $16^{\text {th }}$ century. Similar portals can be found in large numbers in the Wawel 
Castle, monastery buildings in Kraków and Kazimierz and Kraków's tenement buildings and palaces; f) piece of a column with relief sculpture in the form of slanting check pattern filled with rhombi. This is a part of a pier placed between windows in an official room of a tenement building located in Kraków which dates back to the second half of the $15^{\text {th }}$ century or the turn of $15^{\text {th }}$ and $16^{\text {th }}$ century. The collections include unidentified pieces that still have not been analysed by researchers. In the recent years the stonework collection from the Czapski Museum was divided and some of the exhibits were moved to a new location by the Granary. It is a small collection that includes exhibits from a few periods. The details are displayed outdoors under a roof, on shelving units, and labelled with an accession number. Due to the large number of exhibits within a limited space, exhibits other than those on bottom shelves placed in the first row are not easily visible. In some instances, it is difficult to see the origin and resemblance to the preserved and complete historic sites (Fig. 2).

\section{Examples of Gothic stonework remaining in situ in tenement buildings. Portals, window and door frames, piers}

A walk around the city centre of Kraków might help us find architectural analogies with pieces found in stonework collections. This way it is possible to observe authentic elements in a historical context and natural daylight. Gothic details preserved to this day can be found in places that are not easily accessible, primarily in today's basements (formerly, the ground floor), hence they are not widely known or easily observable. Many of the old details survived in halls, outbuildings, facades facing the inner court. The largest group of preserved architectural details is made up by portals. In a sample block of buildings between Floriańska, Szpitalna, św. Tomasza and św. Marka Streets there are 37 preserved stone portals ${ }^{2}$. A single-storey tenement building could feature as many as 15 portals. The works were simple - the only decoration was simple chamfering of jambs and lintels (also found in later works). Some portals were right angled, but a semi-circular finish was more common. "The basements of Kraków boast several hundred portals, all made of high-quality Jurassic limestone". ${ }^{3}$ Pointed portals typical of the Gothic style are less common than semi-circular portals and beam portals ${ }_{1}^{4}$ it is believed that they date back to the $14^{\text {th }}$ or $15^{\text {th }}$ century. The most beautiful examples can be seen in the facades of houses at 8 Floriańska Street and 9 św. Jana Street. A group of extravagant portals with multi-layered moulding were built in the late Middle Ages. They rely on the models used in sacred architecture (e.g. the south nave and vestibule of St. Catherine's Church), ${ }^{5}$ and popularised, e.g. by a construction team working for Jan Długosz (the so-called Długosz portals after 1460 ). ${ }^{6}$ Similar portals are present in large numbers and can be found in more exposed parts of medieval houses (e.g. tenement buildings at 15 Rynek Główny Square, 10 Bracka, 41 Floriańska, 9 Szpitalna Streets, 4 pl. Mariacki Square, 7 Mały Rynek Square $)^{7}$ with the most beautiful being the entrance portals of tenement buildings at $8 \mathrm{pl}$. Mariacki Square and 8 Szpitalna Street (Fig. 3). The width of gate portals within facades (8 Szpitalna Street - 1.35 m, 8 Floriańska Street -2.60 m, 9 św. Jana -2.15 m) might indicate that these gates were passable. ${ }^{8}$

Window frames are more difficult to recognise. They were removed and rebuilt much more often than the portals, and more susceptible to damage. Stone window frames began to be used in Kraków in the second half of the $14^{\text {th }}$ century. It is probable that for a long time they existed alongside brick jambs that were typical of the first stage of tenement building construction. Examples include two significantly splayed openings in the house at 11 Rynek Główny Square, which date back to the second half of the $14^{\text {th }}$ century. The stone frames, usually

2 Swaryczewski 1988, p. 24 Swaryczewski Andrzej, 1984 Gotyckie i gotycko-renesansowe filary międzyokienne odkryte w ostatnich latach w domach krakowskich, "Teka Komisji Urbanistyki i Architektury", v. 18, p. 37-46; 1985 Gotyckie portale w kamienicach Krakowa, "Teka Komisji Urbanistyki i Architektury”,v. 19, p. 9-16; 1988 Gotycki blok lokacyjny nr 9, „Teka Komisji Urbanistyki i Architektury”, v. 22, p. 19-22.;

3 Swaryczewski 1985, p. 9. Cf. Jamroz 1983.

4 Jamroz 1983, fig. 26.

5 Marcin Szyma, Nawa południowa i kruchta kościoła Św. Katarzyny na Kazimierzu w Krakowie. Zagadnienia chronologii, warsztatu i stylu, „Rocznik Krakowski", v. 60: 1994, p. 19-49. Cf. Miłobędzki 1978b, p. 85-86. Also Grzybkowski 2014, p. 122-123, with presentation of alternative theories about the origins of portals.

6 Anna Buczek, Mecenat artystyczny Jana Długosza w dziedzinie architektury, [in:] Dlugossiana. Studia historyczne w pięćsetlecie śmierci Jansa Długosza, Kraków 1980, p. 121-130.

7 Swaryczewski 1985, p. 12-14, fig. 9.

8 Measurements by Franciszek Mączyński, Stary Kraków. Ulice, bramy, sienie, Kraków, 1908, no. 22, 28, 32. 
in the form of straight blocks with chamfering of various widths and a straight lintel were a standard solution. Complex mouldings were less common. The decorative side (with chamfering or moulding) of the windows installed in facades faced the street, at the back of the building it faced the interiors. ${ }^{9}$ The official ground floor room had decorative windows that overlooked the inner court. The windows installed in deep, fragmentarily closed niches were (usually) given stone frames with rich moulding. The windows were additionally decorated with vertical divisions. Some beautiful pieces remain to this day in tenement buildings at 17 and 26 Rynek Główny Square, 16 Mikołajska Street and 16 św. Jana Street. Window seats were commonly built under the windows. ${ }^{10}$ Examples of medieval window stonework preserved to this day can be found in buildings at 14 Mikołajska, 14 Szpitalna, 3 Sławkowska Streets and in 2 Mały Rynek Square. Among Kraków's Gothic stonework and rich tenement buildings of the middle class and knights, a special place is held by piers between windows - decorative compilations of circular posts with cores adorned with geometric patterns, placed between windows. Their notable characteristic is the combination of Gothic (core and base) and Romanesque (massive capitals) styles. Similar piers can be found in houses at Kanonicza and Szczepańska Streets and in Rynek Główny Square. A valuable piece that is representative of this stonework trend is a window taken from the demolished All Saints Parish and installed in the $19^{\text {th }}$ century in the East facing facade of Collegium Maius (Fig. 4).

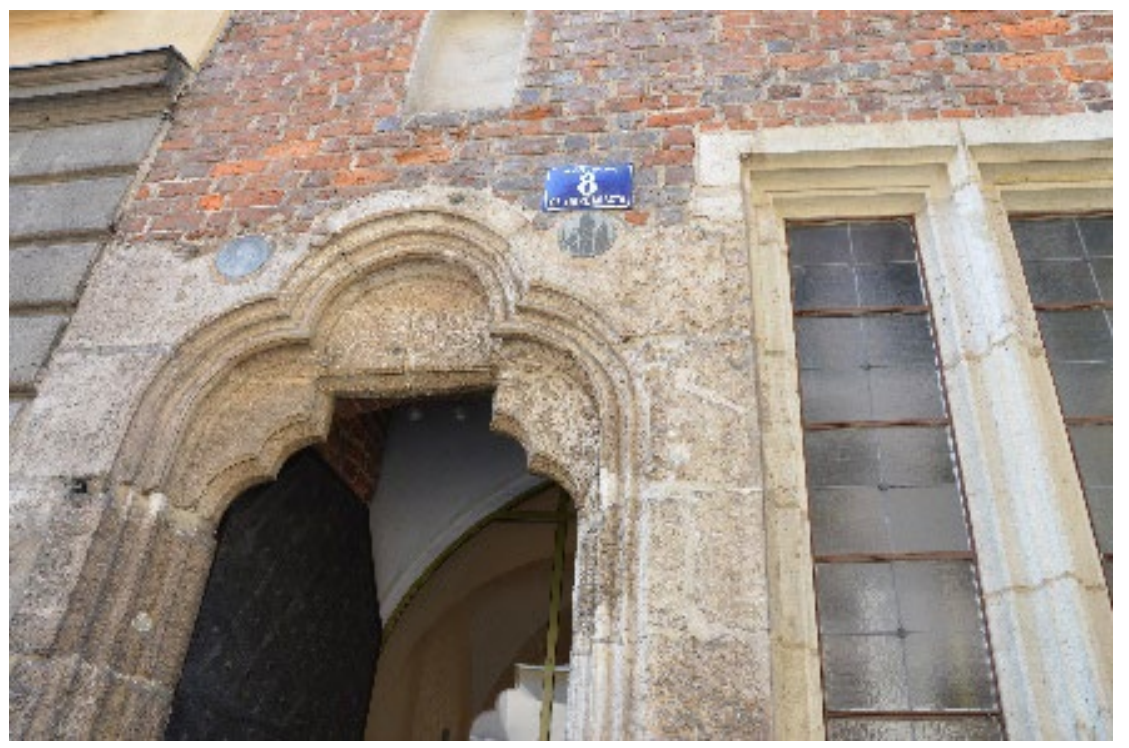

Fig. 3. Kraków, ul. Szpitalna 6

The piers in the houses at Kanonicza Street are noteworthy examples: house no. 3 has a pier which dates back to the mid- $14^{\text {th }}$ century, the pier in house no. 5 dates back to the mid- $15^{\text {th }}$ century, the pier in house no. 7 dates back to the early $16^{\text {th }}$ century. The building at 42 Rynek Główny Square ${ }^{11}$ and Libraria Collegium Maius have piers that date back to the early $16^{\text {th }}$ century. One of the most interesting pier decors can be found in the back room of the tenement building at 5 Szczepańska Street. Aside from fluting on the central column, there are sets of zigzagging grooves on the side columns. The piers between windows along with supports of wall niches and portals, sometimes with vaults, are an integral part of interior design. One example are the ground floor interiors of the house at 5 Szczepańska Street. The piers here feature simple capitals and Romanesque-like decors, portals with rich ornaments and supports of vault ribs.

9 W. Komorowski, Średniowieczne domy w nowożytnym Krakowie, [in:] III Forum Architecturae Poloniae Medievalis, Politechnika Krakowska Architektura series, monograph no. 425, ed. K. Stala, Kraków 2013, p. 131-155;

10 Swaryczewski 1984, p. 37-38, fig. 2, 3, 16. - Swaryczewski 1988, p. 22, fig. 8.

11 W. Komorowski, Dom Bonerów przy Rynku Głównym 42 w Krakowie, "Rocznik Krakowski”, v. 76, 2010, p. 32-35. 


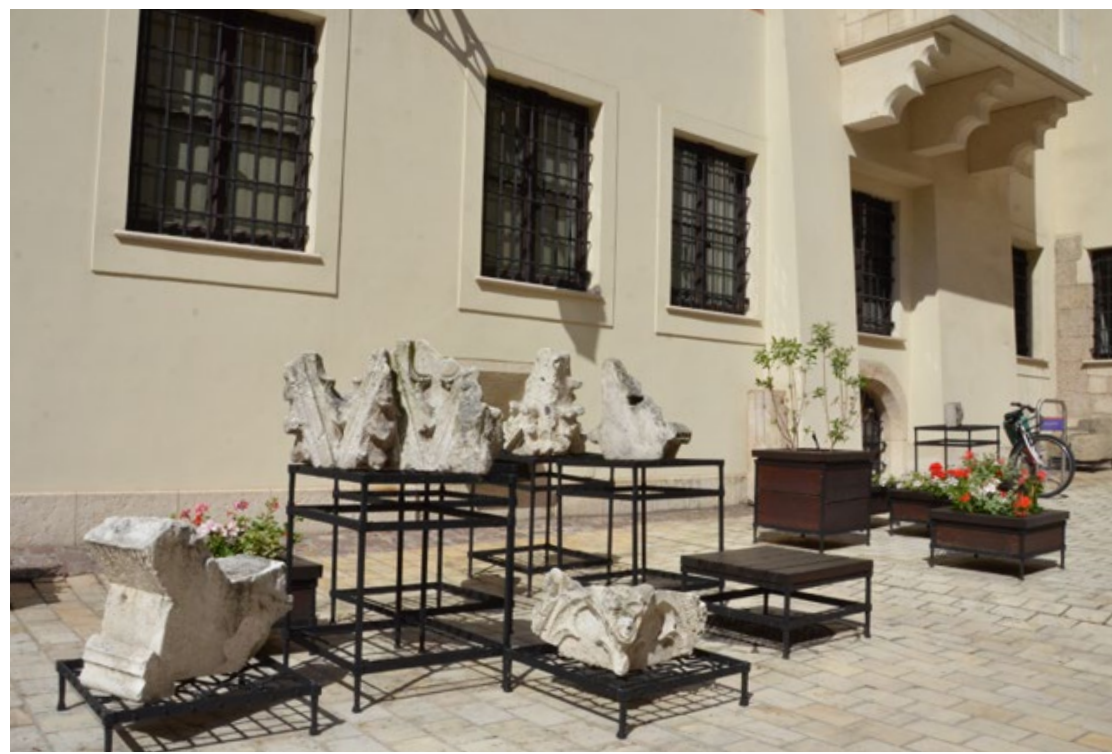

Fig. 4. Kraków, ul Kanonicza 17

\section{Restored and original pinnacles and wimpergs}

The skill and creativity of medieval stonemasons are reflected in effective shapes of pinnacles ${ }^{12}$ and wimpergs. ${ }^{13}$ Between the $14^{\text {th }}$ and $16^{\text {th }}$ century in Kraków and the adjacent Kazimierz pinnacles were built on facades of large churches and imposing buildings that fulfilled other functions. Pinnacles that remain to this day include the ones on Saint Mary's Church in Kraków (presbytery buttresses); the Corpus Christi Church (top of West facing facade) and St. Catherine and St. Margaret's Church (presbytery buttresses, south nave and vestibule) in Kazimierz. An example of small sacred architecture is the Gethsemane Chapel by St. Barbara's Church in Kraków (early $16^{\text {th }}$ century). Buildings that fulfilled other functions included: Collegium Maius (top of the hall), Cloth Hall (buttresses). In the Middle Ages the facades of some of the tenement buildings in Rynek Główny Square in Kraków featured pinnacles.

The monumental presbytery of Saint Mary's Church enclosed on five sides is surrounded by buttresses. The presbytery buttresses (with stone drip cornices on chamfers) are four storeys in height and stand on a low stone plinth. The precise stonework of the beautiful architectural finial is made of dressed Jurassic limestone. The architectural finials of the presbytery are constructed in line with the contemporary model known as aedicula. The core of the composition is a horizontal form, a small structure (chapel) surrounded with muntins, whereas the front features a turret made of a pinnacle or its creative variation. Above the pinnacle on the south buttress of the altar wall there is an emblem of the Republic of Poland. For now, after conservation work and replacement of damaged elements ${ }^{14}$ (reconstructed by architects Tadeusz Stryjeński and Zygmunt Hendel $-19^{\text {th }}-20^{\text {th }}$ century) on the presbytery buttresses there are ten aediculae with pinnaces - turrets. ${ }^{15}$ The Gothic pinnacle found in the Czapski garden was moved there after replacement work on the building.

The main nave is surrounded by buttresses with a single-sloped drip mould (with crockets on the edges) that turns into a double-sloped roof decorated with crockets on the edges and crowned with a fleuron. Under the roof there is a smooth triangular gable. The stonework of the buttresses is made of carefully dressed

\footnotetext{
12 Architectural ornament resembling a small turret, usually with a square core and a pyramidal cap; characteristic of Gothic architecture. It topped rooftops, buttresses, portals, wimpergs, etc. The sides of a pinnacle often take the shape of wimpergs with tracery (muntins on the edges of the core) and the cap is decorated with crockets on the edges and fleurons on the top.

13 In Gothic architecture and stonework a decorative triangular finish with tracery, topped with a fleuron or pinnacle and decorated with crockets on the edges. Wimpergs were built above portals and windows or were used as an ornament on pinnacles.

14 Sudacka A. Prezbiterium k.Mariackiego w Krakowie. Historia prac restauratorskich konserwatorskich, Kraków 1998.

15 Catalogue record by S .Sławiński.
} 
Jurassic limestone. Most of these elements are reconstructions made during the interwar period under direction of the architect Franciszek Mączyński.

\section{About the Gothic stonework in Kraków - general information about function and forms}

The medieval masonry residential buildings in Kraków $\left(14^{\text {th }}\right.$ to early $16^{\text {th }}$ century) usually featured door (portals and door frames) and window stonework, commonly made of Jurassic limestone. This building material came from nearby quarry owned by the city. The stonework was used to install doors, large gates and windows. The stonework also included: stone claddings, columns and piers between windows that served as both a construction element and a decoration. Stone supports were used as a structural element of a wooden porch (corbels). ${ }^{16}$

The characteristics of Gothic stonework included excellent workmanship and an abundance of mouldings. Chamfering was used as a simpler alternative. Aside from pointed portals, there were portals with a straight lintel, some of them with a lot of ornaments. The windows were always rectangular with larger openings divided by stone mullions into smaller openings. In the $16^{\text {th }}$ century there were multiple stone workshops associated with Italian sculptors, e.g. the workshop of Francesco the "Florentine" operating by the Wawel Castle ${ }^{17}$. His most prominent work in the city is the stonework at Erazm Ciołek Bishop of Płock Palace at 17 Kanonicza Street (currently a branch of the National Museum). Francesco the "Florentine" is believed to be the originator of a late Gothic portal with a straight lintel and Renaissance cornice.

The Gothic window frames characteristic of the period, with thin mullions on a base that resembled a screw, were also given a Renaissance cornice. Works of this kind were created by Benedykt who worked at the Wawel Castle. Similar stone works were created in the first half of the $16^{\text {th }}$ century for Collegium Maius (the Library) as well as tenement buildings and palaces and monasteries throughout Kraków and Kazimierz. The essence of late Gothic is the cloister in the courtyard of Collegium Maius with diamond vaults. The moulded arches of the arcade are supported by round columns decorated with crystalline details. Throughout all the periods the same types of Gothic and modern stonework as in the tenement buildings (except for prominent historic works) were found in monasteries as well as collegia and university dormitories.

\section{Conclusions from a review of stonework collections}

1. Pieces of architectural details and sculpture can be found in many buildings throughout Kraków: museums, private tenement buildings, seats of institutions, i.e. places accessible to the public, places with limited availability to the public or places that are completely forgotten, concealed (e.g. basements and storage space).

2. The best arrangements of stone works can be found in gardens, parks, courtyards of former palaces and tenement buildings. The exhibits are properly exposed and protected thanks to casting into facade walls in the form of a niche (or into separation walls), installation or placement, for instance, under an arcade or a roof structure.

3. Outdoor exhibitions in gardens are undoubtedly spectacular, but the sculptures are exposed to difficult weather conditions. Their condition quickly deteriorates.

4. Other way to protect and exhibit the pieces, used since the $19^{\text {th }}$ century, is casting stone works into a new place or uncovering the remains of details covered in the past as a result of alteration of buildings, change of style, as is illustrated by the example of St. Mark's Church and its South facing facade with a piece of a Gothic portal or the walls of Collegium Maius.

16 B. Krasnowolski, Krakowskie warsztaty budowlane i kamieniarskie na przełomie średniowiecza i nowożytności, „Rocznik Krakowski”, v. 72 , 2006, p. 94-95, 98, 100; - idem, Pałac biskupa płockiego Erazma Ciołka na tle historii, architektury i konserwacji ulicy Kanoniczej, „Biuletyn Społecznego Komitetu Odnowy Zabytków Krakowa" issue no. 57, April 2007, p. 134; 
5. There should be alternative solutions for arrangement of details of historic architecture - plastic and design tests based on the use of modern technology. Perhaps a competition for the best design of contemporary stonework collection would be a good idea.

6. It would be a good idea to prepare a short illustrated guide to stonework collections in Kraków with specification of stone works characteristic of a given period still present in situ in the historic city centre.

\section{O zabytkowej kamieniarce Krakowa}

Streszczenie: Masywne fragmenty portali, obramień, filarów, które są złożone w lapidariach i magazynach muzealnych nie budzą dziś większego zainteresowania, słabo przemawiają do wyobraźni widzów - ot, głazy odkute, rzeźbione ale niekompletne, rozbite. Czy można to dziedzictwo cenne a trudne w percepcji inaczej ukazać i upamiętnić? Przybliżyć odbiorcy? Warto przywołać tu koncepcje pionierów konserwacji zabytków. Zrealizowane ekspozycje świadczą o postawie szacunku do dziedzictwa i tradycji. Gotyckie detale architektoniczne porzucone w czasach burzenia zabytków w XIX wieku przetrwały gdzie indziej jako „winkrustowane”. Tak stało się w murach Collegium Maius, Pałacu Pusłowskich, Lubomirskich, Pałacu Ciołka, Domu Pod Stańczykiem. Ocalone przed zniszczeniem i zapomnieniem zdobią wciąż - elewacje, wnętrza, galerie ogrodowe. Może idea i przykłady kolekcji lapidarialnych pobudzą do refleksji i zainspirują współczesnych projektantów? 